\title{
Of faith and reason
}

\section{The openly religious stance of the NIH director could have undesirable effects on science education in the United States.}

T he newest book authored by Francis Collins, Belief: Readings on the Reason for Faith, was released in March 2010. A collection of essays addressing the rationality of faith, the book reflects the struggle of great minds of the past and present—philosophers, poets, scientists- to understand the urge to believe in a supernatural power. It is advertised as an essential companion for anyone seeking clarity in the ongoing debate between reason and faith: seekers, believers and skeptics.

The publication of the book has great potential to reignite some nagging doubts over the election of Francis Collins as director of the National Institutes of Health (NIH). Many hoped that after his nomination he would refrain from publicly discussing his religious convictions. Yet although he stepped down from projects such as Biologos, which attempts to reconcile evolution with the idea of God, and most agree that Francis Collins is a skilled administrator, there are justified concerns that such public embrace of religion from an influential scientist may have negative consequences on science education.

Strikingly, despite being a world leader in science, the United States still struggles when it comes to scientific education. Creationism is creeping back into the science curricula of public schools. And although intelligent design, the latest form of creationism, suffered a major defeat in the 2005 Kitzmiller v. Dover Area School District trial (Nat. Immunol. 7, 433-435, 2006), when a US federal court ruled that including it in science curricula is unconstitutional, creationists are making a comeback.

In 2008, Louisiana state legislators passed bills that allow "open and objective discussions of scientific theories being studied, including but not limited to evolution and the origins of life." In 2009, the Texas Board of Education set new standards for incorporating ideas from intelligent-design literature, including doubts that the fossil records represent convincing evidence of evolution. Under the guise of promoting 'critical thinking skills', such decisions allow creationists to teach the controversy-a strategy designed to discredit evolution and introduce intelligent design as a viable alternative. Opponents of these bills justly point out that such discussions belong in religion, culture and philosophy classes but not in the science curricula.

In an interview by the Pew Forum on Religion \& Public Life, Francis Collins admitted that the United States has done little over the past 150 years to convey the ideas of Darwin's evolutionary theory in the school setting. It should not come as a surprise, then, that only $13 \%$ of the US population believes in natural evolution in which God plays no role. According to Gallup polls, $45 \%$ of Americans believe God created humans, whereas about $40 \%$ believe in a God-guided evolutionary process. Those percentages have not changed in the past 30 years. This is in striking contrast to most European countries and Japan, where $70-85 \%$ of the adult population believes evolution to be absolutely true. A study published in Science (313, 765-766 (2006)) correlated such creationist views with other aspects of US culture. A substantial number of people in the United States have a poor understanding of the core ideas of twentieth- and twentyfirst-century biology, and less than half of US adults can provide a minimal definition of DNA.

There is strong politicization of the evolution issue in the United States. Ronald Reagan ran his presidential campaign in the South and Midwest with speeches into which he would slip the sentence "I have no chimpanzees in my family." In the 1990s, the Republican platforms in seven states included explicit demands for the teaching of creation science. No major political party in Europe and Japan uses opposition to evolution as a part of its political platform. President Obama promised a de-politicization of science and now needs to take steps in scientific education to rectify this situation.

Given that US culture has a tendency to blur the distinction between man and office, the nomination of someone with strong evangelical convictions as the director of the $\mathrm{NIH}$ can further muddle the creationistversus-evolutionist debate in science education. Although written before his nomination, the new book is being promoted using the author's credentials as director of the NIH. In the introduction and in interviews surrounding the book release, he describes his belief in a non-natural, non-measurable, improvable deity that created the universe and its laws with humans as the ultimate aim of its creation. Some might worry that describing scientists as workers toiling to understand the laws and intricacies of this divine creation will create opportunities for creationism adepts.

As Collins' personal experience proves, some may end up as believers no matter what-a secular upbringing and a science education. Faith is a choice, one that should be respected. However, it should also be an informed choice, and it is the responsibility of the education system to ensure that schools provide everyone with the most advanced, upto-date view of the world that science can provide. Scientists cannot make up for all the shortfalls of the public education system, but it is part of their responsibility to promote scientific values and principles along with knowledge and to ensure these are passed on accurately by educators. No one should leave school believing that men walked with dinosaurs. 


\section{Erratum: Of faith and reason}

Nat. Immunol. 11, 357 (2010); published online 20 April 2010; corrected after print 2 August 2010

In the initial version of this editorial, it was erroneously stated that Francis Collins did not step down from the Biologos project and that the US Supreme Court, instead of a federal court, ruled the decision in the Kitzmiller vs. Dover Area School District trial. The errors have been corrected for the PDF and HTML versions of this article. 